\title{
Learning from Royal Shell's Logistics and Supply Chain Management
}

\author{
AbdulGhani Gaghman \\ The Bucharest University for Economic Studies, Romania \\ abdulghanigaghman@stud.ase.ro
}

\section{Abstract}

The study is conducted to analysis the supply chain management paying special attention to the logistics. The aim is to understand the impact of logistics on organization performance, also to help in identifying opportunities for cost/time removals and/or value adding along the supply chain. The company chosen for the study is Royal Dutch Shell Plc. As Shell is the one of the big-gest Oil and Gas Company known in the world and one of the leaders of logistic and supply chain management. Though Shell is working efficiently for providing customers with quality services still there are issues with the supply chain which should be taken care of in order to be much better. These factors grouped in Control the Cost, Planning and Risk Management, Suppliers/Owners Relationship Management. Study concluded with some suggestions can be adopted by any organization aiming for better performance in supply chain.
Keywords

logistics, supply chain management; oil; gas

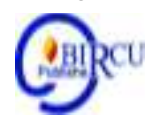

\subsection{Company Overview}

Royal Dutch Shell Plc popular by the name Shell is Anglo-Dutch multinational company, head-quarters in Netherlands and is incorporated in UK (About Shell). Among various oil and gas companies, it is listed as a respected and known company. It topped in the list of Fortune Global 500 list of companies in 2013 (CNN. 2012). Shell is active in various areas of oil and gas indus-try. The Company has setups in around more than 70 countries around the world and operates on two businesses segments-upstream and downstream. its strategy is "More Upstream, Profitable Downstream,"by using the latest technology and innovation for sustainable development that delivers growth for shareholders www.shell.com.

\subsection{Organization Structure}

Shell is a multi-national company with operations all around the world. The structure for the company is Tall structure (Tall structure is one of the structures having different tasks handled by different supervisors, the level of authorities are more in tall structure) (Anderson, 2010). Man-agement studies introduces Supply Chain Management as part of the organization hierarchy aim-ing to enhance the competitive, reduce cost and effectively use resources (Jiashan, 2012). The SCM is missing in this organization structure for shell, where the supply chain planer need to be in communication with other functions and collaborate more effectively. Moreover, the SCM is not part of overall business structure (Figure 1). 
Konfrontasi Journal: Culture, Economy and Social Changes, 7 (1) March 2020, 91-104

ISSN: 1410-881X (Print), 2716-2095 (Online)

AbdulGhani Gaghman: Learning from Royal Shell's Logistics and Supply Chain Management

DOI: https://doi.org/10.33258/konfrontasi2.v7i1.100

http://www.konfrontasi.net/index.php/konfrontasi2

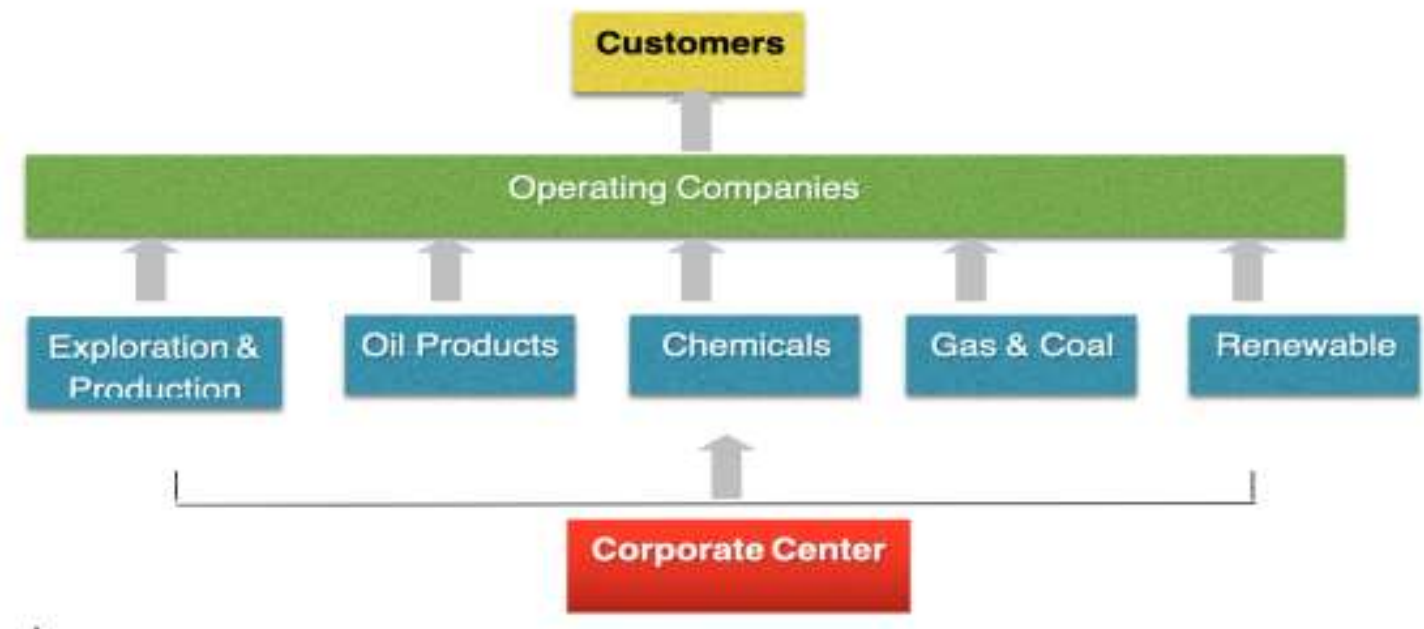

Figure 1. Shell Corporate Hierarchy (Source: Shell.Com)

\subsection{History/Literature of Shell and SCM}

According to Helena Lourenco (2006) in her article, "Supply Chain Management: An Opportunity for Metaheuristics", there is no clear definition of SCM, "but there appears to be some convergence in literature as to what SCM is. However, Mentzer (2005) compiled all the SCM definition in literatures among history and summarize SCM activities in the table below. It is a series of actions which include planning, coordinating, controlling materials providing finished products to customers (Lourenco, 2001).

Table 1. Listed the Scm Activities Based on (Mentzer, 2005 P.8)

\section{SCM ACTIVITIES}

\begin{tabular}{|l|}
\hline 1. Integrated Behavior \\
\hline 2. Mutually Sharing Information \\
\hline 3. Mutually Sharing Risks and Rewards \\
\hline 4. Cooperation \\
\hline 5. The Same Goal and the Same Focus on Serving Customers \\
\hline 6. Integration of Processes \\
\hline 7. Partners to Build and Maintain Long-Term Relationships \\
\hline
\end{tabular}

The success of SCM highly depends on the organization and the information sharing between the various departments and people involved in supply chain (Croxton, 2001). Supply chain is com-plex in oil and gas industry, there are links between upstream suppliers, downstream distributors and information and capital flow occurs around the chain in oil and gas industries. 


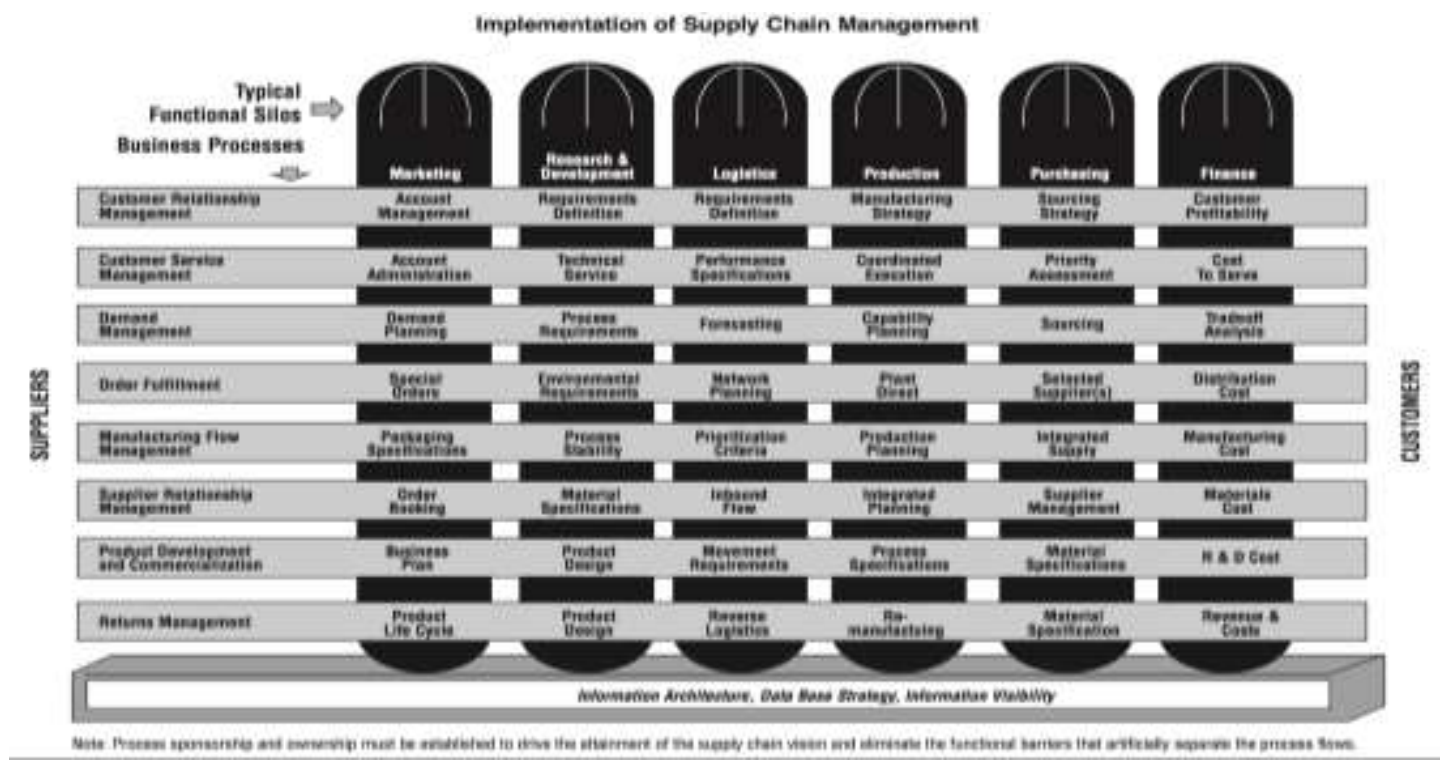

Figure 2. Implementation of Supply Chain Management (Source Croxton, 2001. P.31)

Royal Dutch, the Shell Transport and Trading company (Shell Trading \&Shipping) join together to form Shell Group of companies in 1907. Royal Dutch had a 60\% stake while Shell Transport and Trading Company had 40\% stake. Throughout the 20th century expansion of the company was in Europe, Africa and the Americas. In 1920's and 30's Shell expanded into new regions and sectors of the business. 1960's were dedicated to creating its presence in the middle-east. 70's was targeted to oil and gas discoveries in the north seas. In 1980 Shell started selling unleaded petrol.

In 2002, Shell took over Enterprise oil. It also proceeded with the construction of petrochemicals complex in China. In 2003, Shell focused on alternate sources of energy, it entered into a partner-ship with General Motors. It also entered the European wind energy market. In 2004, the target was Germany market and Portugal.

Every year, Shell came up with new ideas and agreement with various other companies to im-prove its market share and value keeping in mind the innovations in oil and gas industry. In 2009, it signed a series of agreement with Qatar Petroleum International. 2010 also was joined ventures and agreement year with various industries.

Nowadays, most of the businesses do not compete only with an autonomous organization but rather as supply chains. Mentzer et al (2001) defined the Supply chain as a set of upstream and downstream flow (i.e. products, services, finances, information) for a customer from the source.

Supply Chain is a link of relationships in business and this business success depends on the net-work of relationships within the company. Nowadays the real competition is among the supply chains not between companies (Christopher 2012). Mentzer (2001) suggested that, companies working with the involvement of supply chains will succeed in today's world, the work style would be working closely with partners to accomplish the objectives and targets. The oil and gas industry more aggressive than other energy industries in implementing the best SCM practices toward the greater profitability see (Figure 2). 


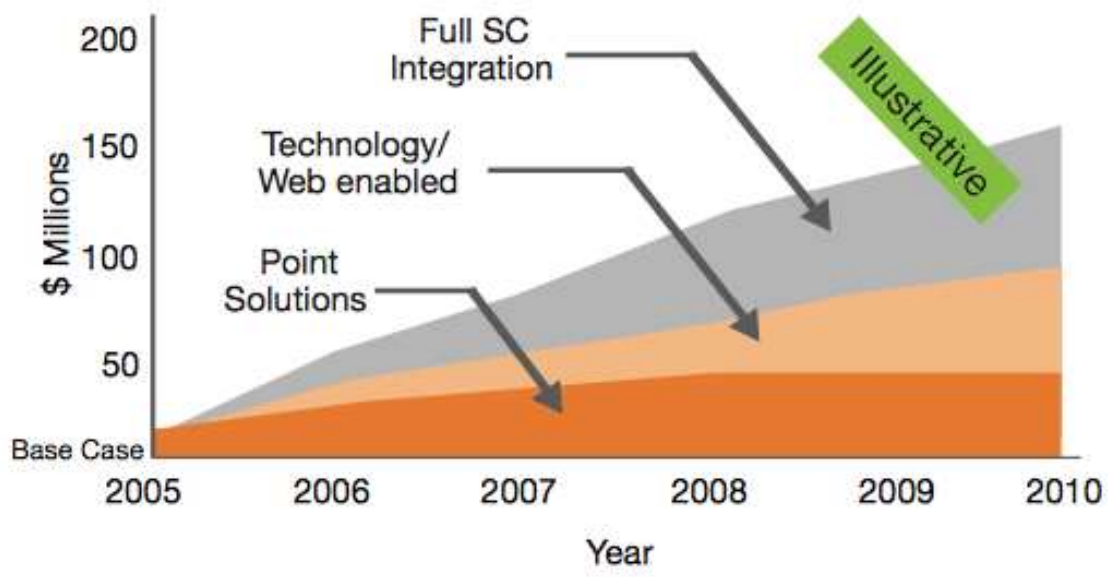

Figure 3. Shows The Supply Chain Economic Potential (Source: Latheef, 2008 P.3)

Many authors analyze different SCM practices based on different industries for instant imple-mentation to make various decisions for example Ferreira and Padula's (2002) studied the beef supply chain, Mollenkopf (2005) research on the food industry, and Scavarda and Hamacher's (2001) discussed the automotive industry. Omain (2010) concluded that the chemicals and oil sectors show best SCM comparing to other industries such as food and textile sectors due to global competition, growing demand, huge amount of supply, wide range of products, price volatility and environmental risk. Moreover, the Oil and Gas upstream supply chain networks are vulnerable and subject to many risk for instant; drilling, pipeline operation, transportation and distribution.

In nineteenth a SC reference model has been developed as a process reference for the SC management of which allow users to improve and communicate SCM practices within companies or business units (Ayers, 2009). SCOR used by many companies for faster implementation of ideas to reduce the risk and planning threats. It helps in identifying the risk related to the suppliers and customers. It also helps to evaluate markets, present condition and helps in establishing the new strategies which are helpful for the organization to reduce the risk (Winch, 2003).

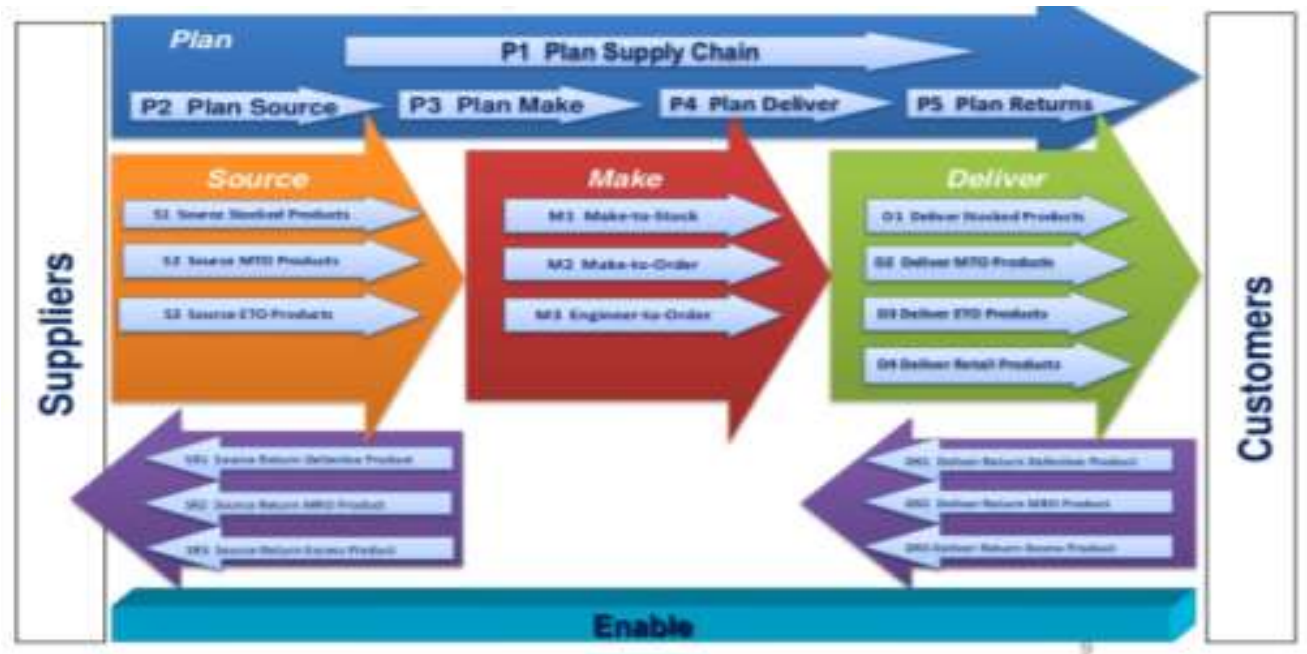

Figure 4. Scor Version 10 Level 2. (Source Ayers, 2009 P.137) 


\section{Review of Literature}

\subsection{Case Study}

\section{Introduction to the topic}

Case study is to study the SCM and logistics for Shell and to understand the effect of this on organization performance. The Supply Chain in today's environment includes many different par-ties which directly or indirectly relate to each other in order to fulfill the objectives of the organi-zations (Li et al., 2005). In earlier days, Supplier chain management was to manage manufactur-ers and suppliers and all the functions and responsibilities they work on. Now the scenario has changed, SCM is needed for managing inventories as well and delivering them to customers. It also focuses on external environment to help grab the favorable opportunities which is beneficial for organization like rates vary on a daily basis, this SCM helps to deal with these daily issues. Thus SCM plays an important role in inventory planning as well. It starts from buying material and delivering to the organization which helps in production on time. In this competitive market SCM and its effectiveness is considered as the important advantage due to which organization cost gets reduced as compared to other competitors in the market, and improve the performance of the company in the market.

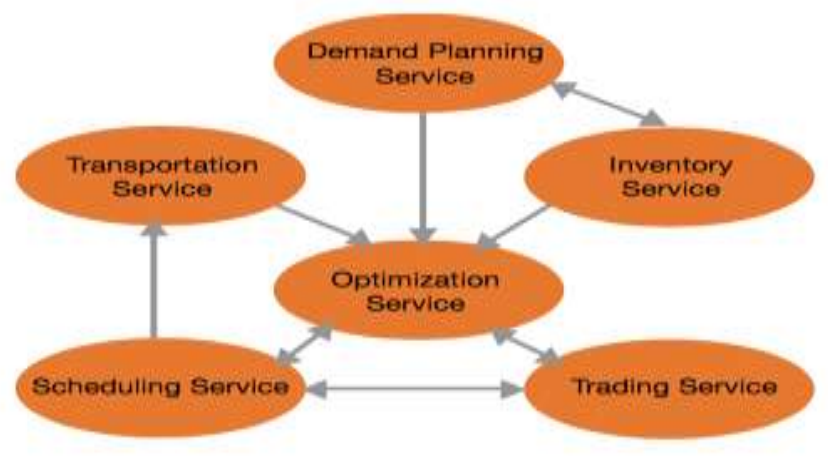

Figure 5. Shows the SCM Optimization Elements

For Royal Dutch Shell Plc, SCM is very effectives they are leaders in providing the best quality to facilitate their customers. As the company is operating all around the world like in US, Brazil, Canada, Denmark, France, Germany, Oman and many more, it gets difficult to provide good quality in oil \& gas, however, company is trying their best to provide the best excellence and quality service to their clients (Shell.com).

Over the last few decades, companies are working hard to reduce the cost and improve the effi-ciencies of the supply chain aiming to deliver products to customers on time and at right cost. There are various techniques which are implemented such as lean production, just in time man-agement, global outsourcing, single source suppliers (Vishwanandam and Kameshwaram, 2013). The supply chain is the link between goods, information and funds and their smooth and easy flow. The biggest challenge faced by the companies was the supply demand matching the need of the customers but today supply chains face many more challenges due to increased complexi-ties (Luo, and Caudill. 2001). 


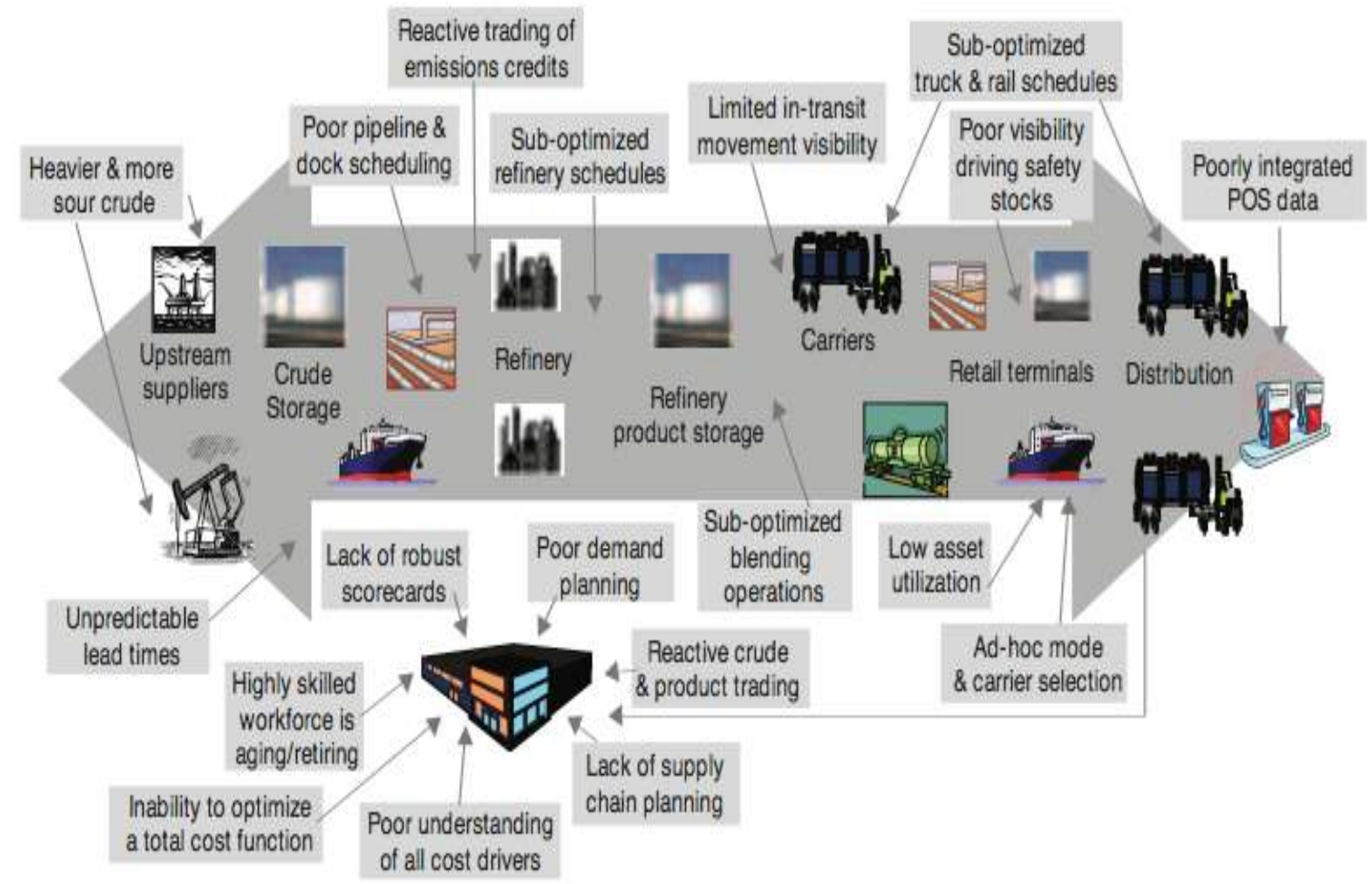

Figure 6. Today's Oil and Gas Supply Chain Challenges (Source: Latheef, 2008 P.1)

The petroleum SC has a high risk associated with significant impact on different economic level. Managing supply risks is the critical component of managing the supply chain. (Fernandez, 2010). Understand or evaluate the risk is crucial for any organization and the most important is how to manage them on time to achieve the success. Sources of risks are many and one needs to be care-ful and should take appropriate action when an undesirable, beyond the control happens. Risks are increasing because of the uncertainties in the company as well as in the ecosystem. Supplier selection is one of the important part in SCM and many processes can be used for selecting sup-pliers (Wang and Yang 2009).

The issue with Royal Dutch Shell is increase in the globalization of businesses so the increasing issues are with supply chain management (Moser, 2005). The companies are constantly working to provide customers with quality services, still working to solve the obvious issues in the supply chain. These issues are cost control, supplier-owner relationship management, planning and risks management, inventory management, etc. 

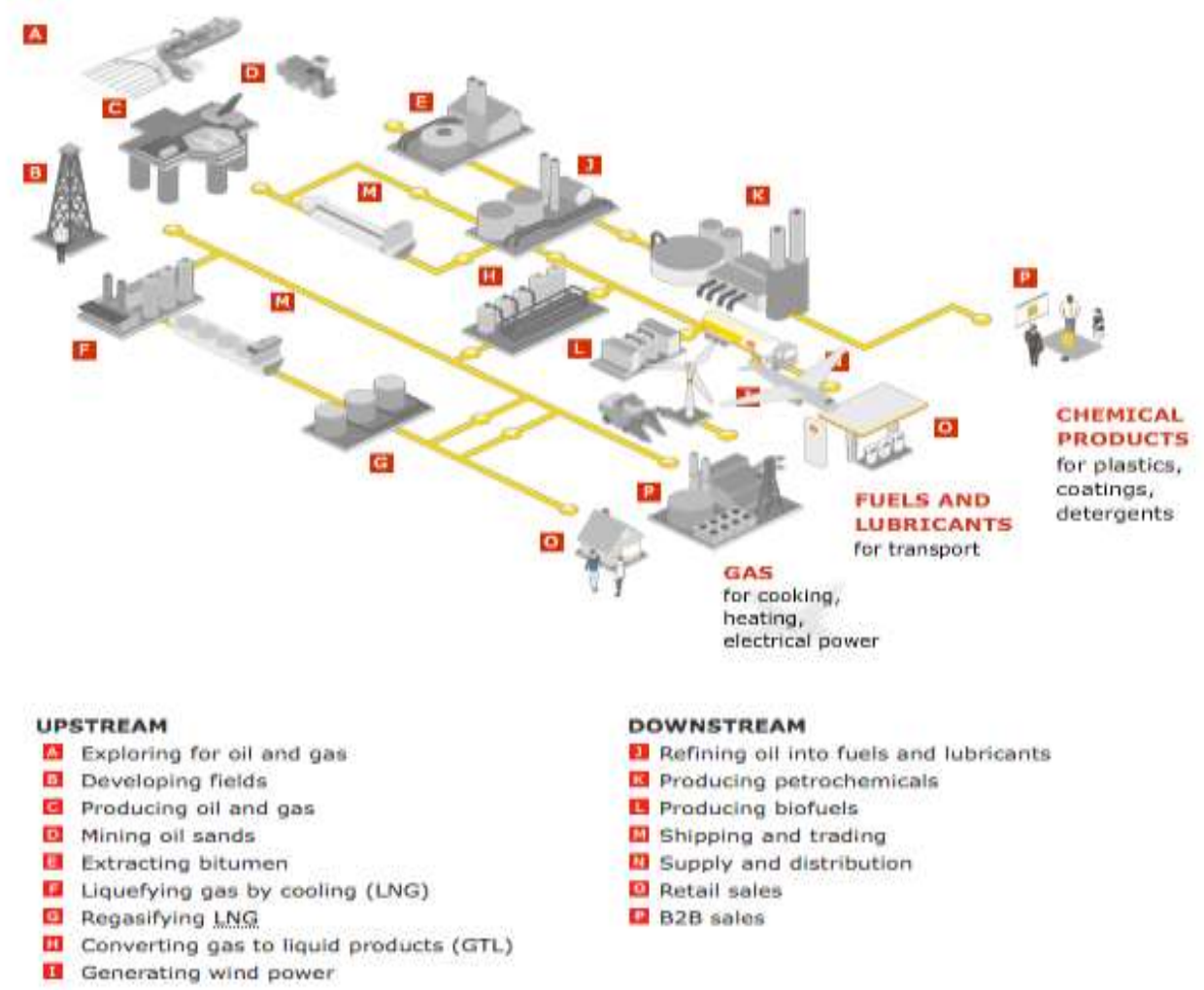

Figure 7. Oil and Gas Supply Chain (Source: Shell Annual Report, 2014)

\subsection{Shell Business Overview}

Shell is a global energy and petroleum company with headquarters in Netherlands and operations all around the world. The company has two business segments: upstream and downstream

Searching oil and natural gas and then recovering it is the upstream business. The upstream segment helps in liquefying and transportation of natural gas and oil along with looking for the infrastructure which would be required for delivery of the oil and gas in the market as per the need. (Our Business).

The downstream includes managing marketing activities and refining done by Shell. Refining includes all the parts such as manufacturing, supply and shipping of oil and gas,.. etc. The down-stream business is for trading crude oil, oil products and petrochemicals. It also provides ship-ping services to LNG carriers (Liquefied Natural Gas) and Oil tankers. (Our Business).

\section{Discussion}

\subsection{Shell's SCM \& Processes}

As we discuss Supply chain is a network of relationships and businesses more than a chain. (Lambert, 2008). However, there are many studies cover more details SC (i.e. logistic planing, inventory planning, process units scheduling, product yield optimization, crude oil supply, etc) but due to limited resources and information confidentiality, This paper used the available data and information from the official Shell website. Shell's Supply Chain processes described as following: 


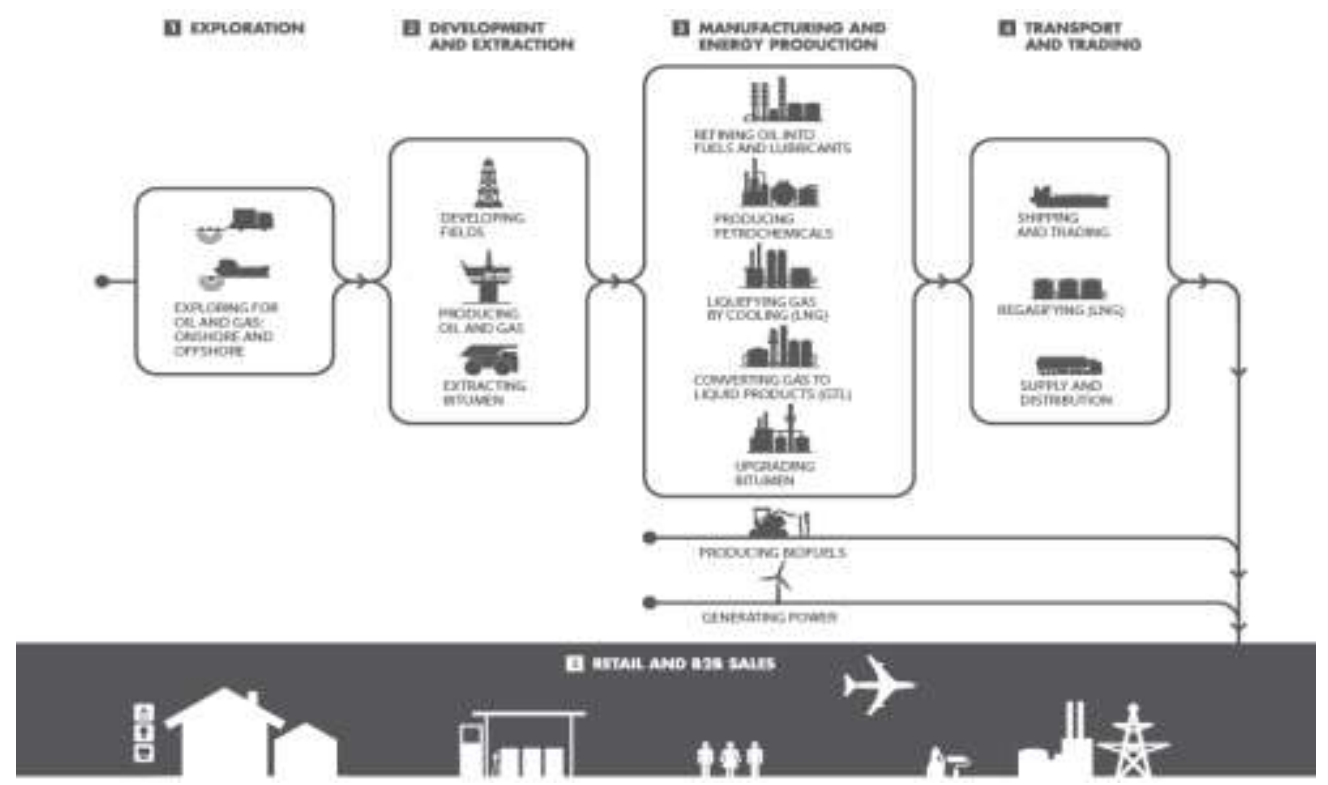

Figure 8. Shell Supply Chain (Source Shell.Com)

\section{a. Produce}

The first step is bringing the oil and Gas to the surface via exploration and development process. Oil production process includes drilling (onshore, offshore), separation the oil from the gas. The daily crude oil production for Shell is about 3.1 million barrels of gas and oil of which consider as a scarce resource (Santos Manzano, 2005). Shell has two main product lines namely fuel and lubricants. In term of SCM the main element here is Crude Valuation, Crude Trading, Logistics.

\section{b. Transport}

At multiple stages of the oil supply chain process, oil is transported to storage, refineries, terminals, and finally to the point of sale. There are four basic modes of transportation of crude oil from production to the market: trains, trucks, ships, and pipelines. SCM elements here; Scheduling and Exchange management.

\section{c. Storage}

Once the oil has been produced, it is transported to short-term storage, refineries or to the export-ed terminal. Storage facilities allow for adjustments in supply and demand throughout the entire supply chain. SCM element such as Inventory Management, Unplanned event response.

\section{d. Manufacturing \& Refine}

Refineries processed or refined the crude oil into various consumer products by using different technique either chemical separation or filtration to produce usable products such as Kerosene, Benzene, fuel oil, Diesel, Jet fuel. Shell has more than 35 refineries. SCM elements here are: Operation Scheduling, Advanced Control, Order execution, Demand Management \& Forecasting and performance Management. 


\section{e. Retail \& Point of Sale}

The final refined product transported to its final point of sale to the market (i.e. fuel stations and airports) using different type of transportation across the country. Mind that the oil and gas industry is a supply driven. Shell has more than 44,000 service station worldwide and 145 Billion liter of fuel sold. SCM elements here Inventory Management, Scheduling and Performance Management.

The Diversity of the main segments that serve the oil and gas SC is summarize in the following graph (IHS, 2015).
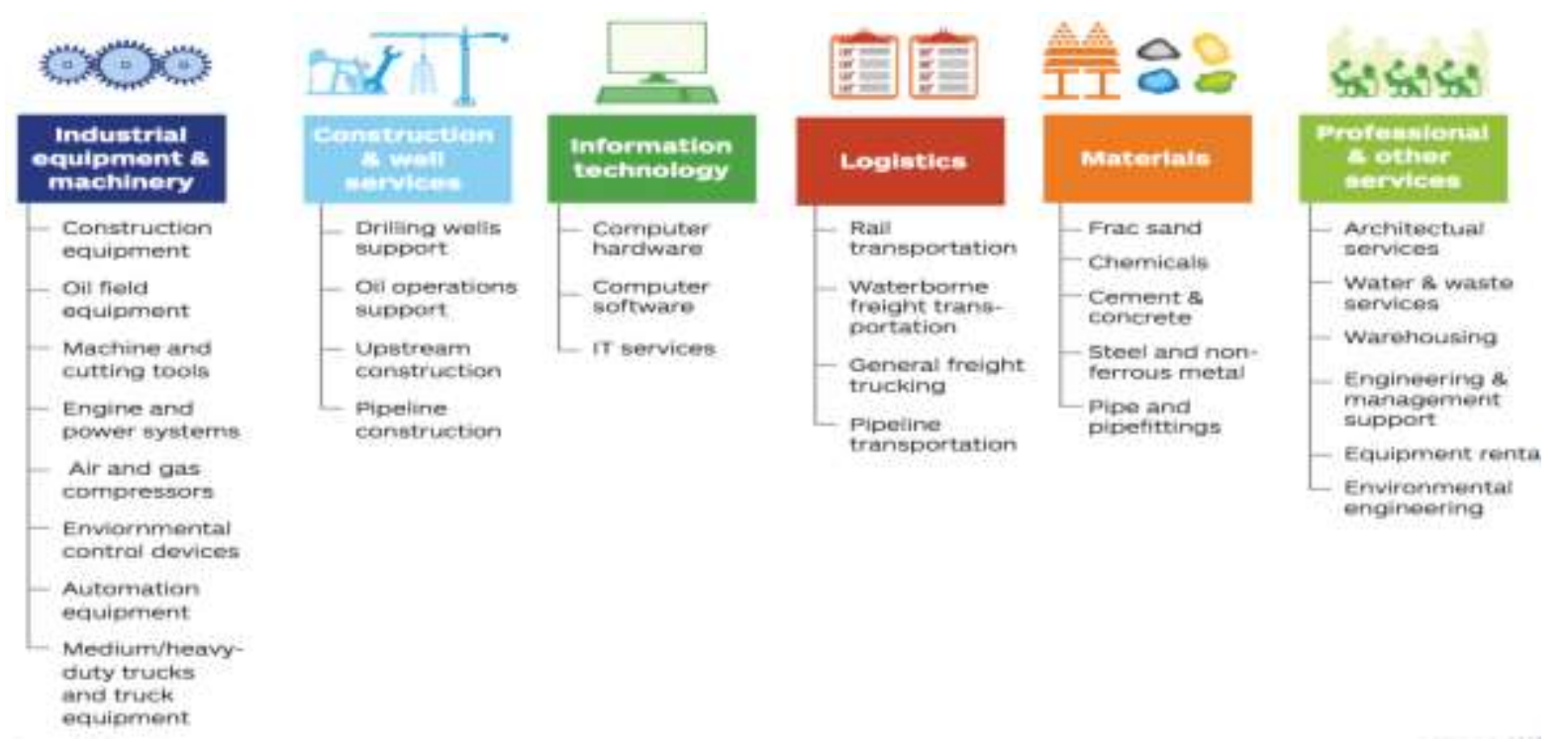

Figure 9. Primary Sectors In The Oil And Gas Supply Chain (Source Ihs Economics 2015)

\subsection{Analysis of Company's Supply Chain \& Processes}

The main performance indicator for SC and logistics focused here are the cost, quality and delivery. As shell has many units and each unit carries out operation in their own way to maximize the sales and profits which results in lack of co-ordination and disorganization within the company. Shell discovered home-grown spreadsheets and application supporting the refineries. Moreover, different supply chain planning and operation processes have been developed in some refineries, which effect the original objective of the company. Shell is also experiencing the delay in the delivery of the necessary items which is resulting in longer production periods and high operating costs.

Another issue with the supply chain is demand variability implication, which by working with supply chain more efficiently can be reduced. The major goal is to provide maximum profits of with optimal service to customers at the lowest cost for the company. Shell used to treat each refinery as a separate entity which harms the profit and efficiency. If various practices are applied supply chain can result in profits and reduction in time of production which is what every company wants, however different countries apply different SCM practice, also recognize variation in infrastructure and IT network (Omani 2010). Another issue faced by Shell is to gather the data and analyze it due to environment constraints and the lack of technology and systems also are responsible for it. Financial loss is often linked with a reduction of upstream and downstream profitability, but if we work on the supply chain and devise it according to the requirements, it can be the best solution for maximizing the profits (Chima, 2007). With effective information sharing and innovation, there will be a reduction in costs and improvement in production among the supply chain. 


\section{Conclusion}

\subsection{Issues in Supply Chain at Shell}

Though Shell is working efficiently for providing customers with quality services still there are issues with the supply chain which should be taken care of in order to be better. These factors can be grouped in Control the Cost, Planning and Risk Management and Suppliers/Owners Relationship Management (Abouhenidi, 2013) lack of co-ordination and disorganization, gathering data and analyzing the data etc. Another issue with supply chain is demand variability. There is increasing number of issues of SCM due to the globalization of the businesses and competition (Moser, 2005). Details are discussed below:

a. Cost Control: Supply Chain management helps in delivering goods on time but due to increasing businesses within the countries and increasing globalization, It is becoming difficult to deliver on time. SCM is using freight mode which adds to the extra costs to deliver the best survive to the customers (Boyle, 2002). Fluctuation of fuel prices also adds the cost for the supply chain and acts as a threat for it.

b. Planning and Risk Management: This is as the case where supply chain management helps to predict the prices and there can chances of errors as the prediction is done on the basis of previous results resulting in high risk to SCM. The schedule of the primary logistic as well as the planned pickups/deliveries ex-depot for the upcoming days is not available in a consistent, integrated tool but rather isolated information in local functions. Organiza-tions can lose their image due to the poor performance, so company needs to work hard to achieve a desire result which involves a lot of technicalities and good planning (Moser, 2005), (Fernandez, 2010). Briggs (2010) listed the main sources of oil supply chain risk and vulnerabilities represented in: Exploration and Production Risks, Environmental and Regulatory Compliance Risk, Geopolitical Risk, Transportation Risk.

c. Suppliers/Owners Relationship Management: Shell is known globally and has opera-tions all around the world. Diverse rule within different countries make it difficult to measure the quality and this can create a conflicts between owners and suppliers (Boyle, 2002).

\subsection{Shell Intervention and Strategies}

Most of the projects of shell are technology driven and it helps the company to lower inventory costs. Shell has various other strategies apart from technology. These are use one of the best mode of freight, high skilled staff, and clear rules \& policies in oil and gas products for evalua-tion. These are the used by the company to reduce the issues coming in the supply chain and are work related (Halldorsson, 2008). These strategies help to reduce the issues but they do not get over.

Shell's SCM added lots of values in term of reducing the cost, optimize the sale network and en-hance management efficiency. These are some of the correct strategies recognized by Royal Dutch Shell Plc which are helping the company to work with the issues and help them to reduce the issues related to (SCM) (Internal report).

1. Optimization / increase scheduling accuracy

Enabling short term optimization / increase scheduling accuracy targeting the costs and benefits as part of SC.

a. An optimized (minimal costs) primary logistic schedule based on constraints and availabilities

b. An integrated information base for all operational and tactical supply chain decisions

c. Transparency (Management reporting)

d. Automation to reduced manual efforts

2. Project Forecasting Improvement: 

a. Volume upload as monthly planning volumes (including volume tolerances and prices)
b. Simplified Envelope Model (Supply Network Optimization- treat all refineries as one envelope)
c. Integrated Sales and contract management

3. For minimizing the risk level company has appointed competent employees who are keeping an eye on market conditions and are effectively working on it.

4. Implement technology to allow timely management and control of the product supply chain

5. Shell designed and implemented integrated sales \& logistics scheduling tool as following:

a. Create a consistent and feasible initial logistics schedule based on monthly optimization.

b. Provide integrated information for operational /tactical supply chain decisions.

c. Improve cross departments collaboration by providing a common working platform and data base.

The clear policies formed at all the branches for evaluation of oil and gas products by the company are highly helpful in reducing the chances of conflicts and clashes. These policies help in maintaining good relationships between owner and supplier (Jiang, 2002). Szucs (2012) developed a framework for Oil and Gas SC optimization in the figure below which may Shell need to implement.

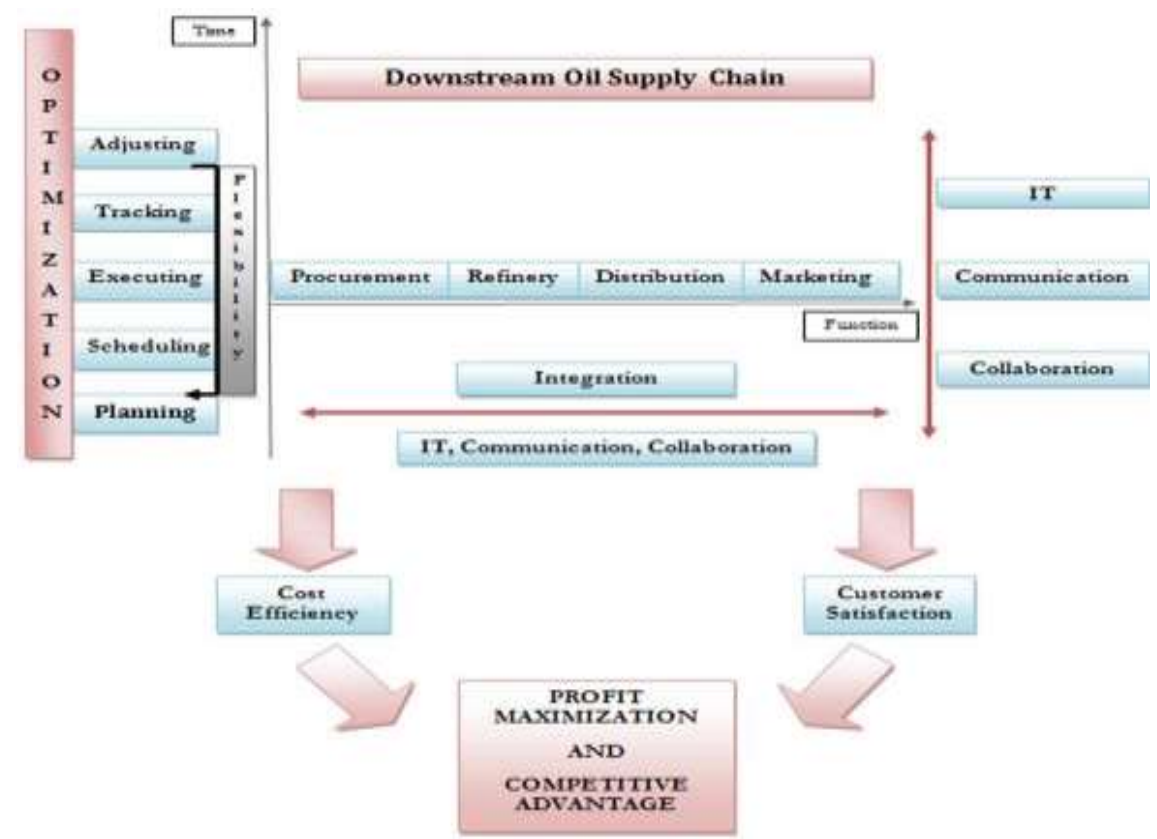

Figure 10. Optimization For Downstream Oil Supply Chain (Szucs, 2012)

\section{Recommendations}

Though strategies used by Royal Dutch Plc are good, here are some of the suggestions for the company which they can work on for better performance.

1. Use and implement of SOCR model- Supply Chain Operation Reference (SOCR) model and Customer-Chain Operations Reference-model (CSCMMP's Process standards), It is the right step in the SC improvement (Jump Start) (Ayers, 2009). 
2. Implement Supply Chain Risk Management (SCRM) framework, by defining a decision tree for the deployment of a risk and the mitigation plan. (Fernandez, 2010).

3. Cost reduction can achieve via better asset utilization, reduce logistics \& distribution costs, improve margins and more efficient selling.

4. Emphasize on Market Value consideration by improving the decision making, increase accuracy and access to performance and increase the reaction to market volatility (Latheef, 2008).

5. Shell SCM management should work on globalize and standardize the SCM processes (ISO/PAS 28000:2005 SC Security, ISO 9001:2000 (Quality) and ISO 14001:2004 (Environmental) (ISO, 2006)and its supported technology solution instead of home-grown application and document.

6. Knowledge is important as it will help to compete for customers and clients. Knowledge management is more important and Shell should focus on creating a culture where knowledge sharing takes place. (Banjoko, 2009).

7. Shell surely needs to find new ways of IT techniques which includes better flow and sharing of information and helps to improve the database. (Tiegland, 2007).

\section{References}

Abouhenidi, H.M. (2013). Royal Dutch Shell Plc and Its Supply Chain Management. International Journal of Scientific \& Engineering Research. 4(8). 671-679

"About Shell". Shell. Retrieved 12 July 2013.

Anderson, C., \& Brown, C. E. (2010). The functions and dysfunctions of hierarchy. Research in organizational behavior, 30, 55-89.

Ayers, J. B. (2009). Handbook of supply chain management. CRC Press.

Banjoko, B., (2009). Shell in the New Decade: The Way Forward. CAR (CEPMLP Annual Re-view). CAR (14).[Available Online: http://www.dundee.ac.uk/cepmlp/gateway/?news=31314 ]

Boyle, E. (2002). The failure of business format franchising in British forecourt retailing: A case study of the rebranding of Shell Retail's forecourts. International Journal of Retail \& Distri-bution Management, 30(5), 251-263.

Briggs, C.A. (2010). An Evaluation of the Upstream Crude Oil Industry Supply Chain Risk: Leveraging Analytic Hierarchy Process. North Dakota State University [available Online: http://www.ugpti.org/events/seminar/downloads/2010-04-08CharlesBriggspdf]

Chima, C. M. (2011). Supply-chain management issues in the oil and gas industry. Journal of Business \& Economics Research (JBER), 5(6).

Christopher, M. (2012). Logistics and supply chain management. Pearson UK.

CNN (2012)."Global 500. Royal Dutch Shell" Retrieved 29 January 2013.

Company Profile Royal Dutch Shell Plc,6-feb-2015, [Online available form: www.marketline.com], Accessed on 6 may 2015,

Cox, R. (2011). 25 ways to lower inventory Costs. Supply Chain Management Review. [Online available

from: http://www.scmr.com/article/25_ways_to_lower_inventory_costs]

Croxton, K. L., Garcia-Dastugue, S. J., Lambert, D. M., \& Rogers, D. S. (2001). The supply chain management processes. The International Journal of Logistics Management, 12(2), 13-36.

Fernandez, L. J., Barbosa-Póvoa, A. P., \& Relvas, S. (2010). Risk Management Framework for the Petroleum Supply Chain. Computer Aided Chemical Engineering, 28, 157-162. 
Ferreira, G. C., \& Padula, A. D. (2002). Gerenciamento de cadeias de suprimento: novas formas de organização na cadeia da carne bovina do Rio Grande do Sul. Revista de Administração Contemporânea, 6(2), 167-184.

Halldórsson, Á., Larson, P. D., \& Poist, R. F. (2008). Supply chain management: a comparison of Scandinavian and American perspectives. International Journal of Physical Distribution \& Logistics Management, 38(2), 126-142.

IHS, 2015. [Available online :https://www.ihs.com/Info/0315/crude-oil-supply-chain.html] ac-cessed 15th May, 2015.

ISO, 2006. International Organization for Standardization, 2006. [Available Online: http://www.unece.org/fileadmin/DAM/trans/bcf/news/documents/ISO28004e.pdf]

Jiang, B. (2002). How international firms are coping with supply chain issues in China. Supply Chain Management: An International Journal, 7 (4), 184 - 188

Jiashan, W., Jingzhong, W. (2012). Supply Chain Management in Petroleum Industry Quan-dary and Countermeasures. Daqing Petroleum Institute, P.R.China, 163318.

Lambert, D. M. (2008). Supply chain management: processes, partnerships, performance. Sup-ply Chain Management Inst.

Latheef, I., Schweitzer, B.,Apicella, M. (2008). Creating The integrated Value Chain for Downstream Oil. Capgemini. [Online: https://www.capgeminiconsulting.com/resource-fileaccess/resource/pdf/tl_Creating_the_Integrated_Value_Chain_for_DownstreamOilpdf]

Li, S., Rao, S. S., Ragu-Nathan, T. S., and Ragu-Nathan, B. (2005). Development and validation of a measurement instrument for studying supply chain management practices. Journal of Operations Management, 23, 618-641.

Luo, Y., Zhou, M., \& Caudill, R. J. (2001). An integrated e-supply chain model for agile and environmentally conscious manufacturing. Mechatronics, IEEE/ASME Transactions on, 6(4), 377-386.

Lourenco, H. R. (2001). Supply Chain Management: An Opportunity for Metaheuristics. UPF Economics and Business, 2001.

Lourenco, H. R. (2006). An Opportunity for Metaheuristics. Metaheuristic Optimization via Memory and Evolution: Tabu Search and Scatter Search, 30, 329.

Mentzer, J. T., DeWitt, W., Keebler, J. S., Min, S., Nix, N. W., Smith, C. D., \& Zacharia, Z. G. (2001). Defining supply chain management. Journal of Business logistics, 22(2), 1-25.

Mollenkopf, D., \& Dapiran, G. P. (2005). World-class logistics: Australia and New Zealand. In-ternational Journal of Physical Distribution \& Logistics Management, 35(1), 63-74.

Moser, T. (2005). Social performance: key lessons from recent experiences within Shell. Corpo-rate Governance: The international journal of business in society, 5(3), 105-118.

Omain, S. Z., Hamid, A. B. A., Rahim, A. R. A., \& Salleh, N. M. (2010, December). Supply chain management practices in Malaysia palm oil industry. In The 11th Asia pacific industrial engineering and management systems conference, Melaka, Malaysia (pp. 7-10).

Santos Manzano, F. (2005). Supply chain practices in the petroleum downstream (Doctoral dis-sertation, Massachusetts Institute of Technology).

Shell Annual Report (2014). [Online available from:http://reports.shell.com/reporthome/2014/index.html\#home]

Shell (2014). Royal Dutch Shell plc fourth quarter 2014 result [Online available from:http://www.slideshare.net/royaldutchshell/q4-2014analystpresentationslides] accessed May, 10th 2015.

Shell. com [Available Online from: http://www.shell.com/global/aboutshell/at-a-glance.html ] ac-cessed 2nd May 2015. 
Shell Trading \& Shipping, [Available Online from: http://www.shell.com/global/productsservices/solutions-for-businesses/shipping-trading.html ] accessed 2nd May 2015.

Shell our Business [Available Online from: http://www.shell.com/global/aboutshell/ourbusiness.html ] accessed 2nd May 2015.

Shell for Supplier [Available Online from: http://www.shell.com/global/productsservices/solutions-for-businesses/supplier.html ] accessed 2nd May 2015.

Szucs, D., Hassen K. (2012).Supply Chain Optimization in the Oil Industry: A Case Study of MOL Hungarian Oil and Gas PLC. [Available Online http://www.divaportal.org/smash/get/diva2:534394/FULLTEXT01.pdf ]

Tiegland, R.(2015). Knowledge Management in Global Firm. [Online available at http://www.slideshare.net/eteigland/knowledge-management-in-global-firm]

Viswanadham, N., and S. Kameshwaran. (2013). Ecosystem Aware Global Supply Chain Man-agement. Singapore: World Scientific Publishing.

Winch, K. J., (2003). Supply Chain Management: Strategy, Planning, and Operation. International Journal of Quality \& Reliability Management, 20 (3), 398 - 400. 